\title{
СЛОЖНОСТИ РАЗВИТИЯ СОЦИАЛЬНОГО ПРЕДПРИНИМАТЕЛЬСТВА В 21 ВЕКЕ
}

\author{
Котов Евгений Сергеевич \\ Научный руководитель: Дмитриев Антон Геннадиевич \\ к.э.н., доцент \\ МФПУ «Синергия»
}

\begin{abstract}
Аннотация: В настоящее время развитие социального предпринимательства набирает обороты во всем мире. Тренд на развитие такого рода предпринимательства сегодня можно увидеть во всем мире. В данной статье мы рассмотрим, с чем сталкивается социальный бизнес в современное время и как решает те задачи, с которыми он сталкивается.
\end{abstract}

Ключевые слова: Социальное предпринимательство, предпринимательство, экономика, современность, инновации, развитие.

\section{THE SPECIFICS OF THE DEVELOPMENT OF SOCIAL ENTREPRENEURSHIP IN THE 21ST CENTURY}

\section{Kotov Evgeny Sergeevich Dmitriev Anton Gennadievich}

\begin{abstract}
Currently, the development of social entrepreneurship is gaining momentum all over the world. The trend for the development of this kind of entrepreneurship can be seen all over the world today. In this article, we will look at what social business is facing in modern times and how it solves the problems it faces.
\end{abstract}

Key words: Social entrepreneurship, entrepreneurship, economy, modernity, innovation, development.

В настоящий момент социальное предпринимательство один из способов государства выполнять свои социальные обязательства перед населением не используя государственные ресурсы. В 21 веке не только социальные предприниматели, но и весь бизнес столкнулся с проблемами пандемии. В этой 
статье мы рассмотрим основные проблемы с которыми столкнулись социальные предприятия помимо пандемии, локдауна и qr-кодов.

Основные барьеры в развитии социального предпринимательства

- Операционные проблемы включают наиболее часто упоминаемые проблемы (55\%) социальными предприятиями, в том числе набор персонала; поиск свободных помещений и нехватка времени.

- Доступ к соответствующему финансированию остается самым большим препятствием как для стартапов, так и для созданных социальных предприятий. 38\% обратились за финансированием за предыдущие 12 месяцев, что по-прежнему значительно больше, чем у их основных аналогов для малого и среднего бизнеса $(12 \%)$.

- Поиск финансирования и денег на открытие социальных предприятий.

- Более половины (51\%) социальных предприятий считают, что объем внешнего финансирования, доступный их организации, достаточен.

В нашем опросе всем респондентам было предложено перечислить три основных препятствия на пути устойчивого развития и роста. Доступ к финансированию по-прежнему остается основным, наиболее значительным препятствием для устойчивого развития и роста, на которое ссылаются респонденты в пятом опросе подряд. Если мы объединим барьеры получения грантового финансирования и получения долгового или долевого финансирования, то этот показатель составит 43\%, как и в 2017 году. Гораздо меньшая доля (17\%) МСП 1 утверждают, что финансы являются препятствием для их успеха в бизнесе. 14\% респондентов сообщили, что набор персонала является препятствием, что соответствует тому же проценту, что и 2017. Хотя это то же самое, что и в предыдущем опросе, относительно по сравнению с другими проблемами, проблема набора персонала стала более важной за последние два года, поднявшись с 6-й наиболее часто упоминаемой проблемы до 4-й.

О проблемах, связанных с набором персонала, сообщается по всей стране. Однако социальные предприятия в Ист-Мидлендс (18\%) и Южной Запад (18\%), скорее всего, будут ссылаться на вербовку в качестве проблемы. Социальные предприятия на Северо-Востоке были наименее вероятны. Неудивительно, что эти социальные предприятия в наиболее обездоленных общинах были более скорее всего, столкнутся с проблемами при наборе персонала (18\%) по сравнению с наименее обездоленными (15\%). 
Более крупные организации также обнаружили, что набор персонала является более сложной задачей, чем у небольших организаций: $46 \%$ социальных предприятий с численностью персонала более 100 человек ссылаются на эту проблему как на препятствие для роста. Денежный поток является третьим наиболее часто упоминаемым барьером (15\%), который был вторым наиболее часто упоминаемым в 2017 году (23\%), указывая на то, что денежный поток может улучшаться для социальных предприятий. Аналогичным образом, процент тех, кто заявляет о нехватке времени, улучшился - только 8\% считают, что время давление является препятствием для устойчивого развития по сравнению с 16\% в 2017 году. Также положительно то, что отсутствие спроса и экономический климат были названы препятствием только 10\% респондентов. Об этом сообщили 17\% респондентов в 2017 году, что указывает на более оживленный рынок социальных предприятий, что особенно обнадеживает, учитывая более широкую экономическую неопределенность.

Несмотря на динамику развития социального предпринимательства в России, на пути его дальнейшего процветания стоит большое количество проблем, среди которых можно выделить следующие:

1. Отсутствие четких измеримых показателей, отражающих результаты реализуемых проектов. Необходимость в таких показателях (простых и объективных) воз-никает как у инвесторов, так и у предпринимателей. Инвесторы на основании таких индикаторов могут определить качество проектов, их социальную значимость и актуальность. Предприниматели при наличии хорошо разработанных измеримых индикаторов способны привлечь дополнительные денежные средства в свой проект, повысить репутацию, доказать, что организация действует исходя из своей миссии и цели. Основные причины отсутствия четко разработанных показателей:

1) незрелость методов оценки социальных проектов. Не всегда результаты соци-альных программ можно представить в денежном выражении, что приводит к необходимости создания таких показателей, которые смогут отразить весь спектр выгод для общества;у большое разнообразие целей социальных организаций, для достижения кото-рых необходимо проведение анализа. Нет общего мнения по поводу степени влияния социального проекта и уровнем расходов на его реализацию. При этом одни эксперты считают, что такой подход можно использовать для принятия решения о распределении 
денежных средств между проектами, другие считают, что на основе этих данных можно провести только сравнение с аналогичными программами.

2) Отсутствие знаний при формировании организационной структуры социаль-ного предприятия. Многие начинающие социальные предприниматели, считают, что социальное предпринимательство обязательно является некоммерческим. Однако, существует множество форм для его существования, например, коммерческая форма или гибридные структуры. К гибридам можно отнести коммерческие организации с некоммерческими подразделениями, некоммерческие организации с коммерческими подразделениями, некоммерческие структуры с некоммерческими подразделениями, партнерства между некоммерческими и коммерческими структурами, партнерства между несколькими некоммерческими организациями [3,c.140] (Kikal Dzh., 2014).

Bce перечисленные формы обладают своими преимуществами, недостатками и требуют детального изучения. Задача социального предпринимателя- отнестись к выбору структуры очень серьезно, так как в дальнейшем это повлияет на финансирование проекта, степень ответственности, возложенной на предпринимателя.

3. Высокие запросы со стороны государства к социальным предприятиям, которые основаны на стандартах крупных бюджетных организаций. Для устранения данной проблемы необходимо в законопроекте внести требования государства к социальным предприятиям в зависимости от целей и масштаба их деятельности.

4. Дефицит необходимых финансовых средств, банковской поддержки, фондов, социальных инвесторов и заинтересованных лиц. Проведение маркетинговой политики сможет увеличить количество людей, заинтересованных предлагаемыми видами деятельности социальных предпринимателей и привлечь новых инвесторов.

5. Необходимость поддержки социального предпринимательства в малых городах и сельской местности.

6. Низкая осведомленность людей о перспективах развития социального предпринимательства. Данная проблема требует демонстрации лучших примеров реализуемых программ социального предпринимательства, которые будут вдохновлять людей на создание новых проектов. 
7. Низкий уровень подготовки, повышения квалификации сотрудников социаль-ного предприятия. Решение проблемы заключается не только финансовой помощи, но и в консалтинге.

8. Недостаточное количество мер по повышению спроса на предоставляемые услуги и продукцию социальных предпринимателей. Данная проблема требует про-ведения сильной рекламной политики, которая поможет привлечь и увеличить коли-чество заинтересованных лиц.

9. Отсутствие массовой поддержки социального предпринимательства. Для реше-ния данной проблемы необходимо демонстрировать людям больше лучших практик и примеров социального предпринимательства, а также перспективы дальнейшего развития, что необходимо для повышения их заинтересованности.

10. Отсутствие обширной законодательной базы, регулирующей социальное предпринимательство. Согласно новому законопроекту по социальному предпринимательству, к 2018 году частные компании по заказу государства будут оказывать до 20\% социальных услуг, а к 2020 году-60\%.

Как отмечают в Минэкономразвития, государственно-частное партнерство в социальной сфере позволит повысить качество социальных услуг. Усиленная законодательная база позволит укрепить не только отношения с государством, но и привлечь других инвесторов и заинтересованных лиц и повысить осведомленность людей о роли социального предпринимательства.Решение перечисленных проблем будет способствовать развитию социального предпринимательства и его выходу на совершенно новый уровень в России. Именно социальное предпринимательство способно решить многие общественные проблемы, в том числе: бедность, голод, трудоустройство инвалидов, жестокое обращение с детьми, подростковая беременность и т.д. Таким образом, люди должны знать, что каждый из них может вложить свой вклад в развитие общества и разрешить многие волнующие вопросы.

\section{Список литературы}

1. Introduction to Social Entrepreneurship, Chahine T., 2016.

2. Social Entrepreneurship, Paramasivan C., 2016. 